\title{
MANAGEMENT OF INNOVATION IN LANGUAGE TEACHING (A CASE STUDY OF MANAGING INNOVATION IN RURAL SCHOOLS IN NTT PROVINCE, INDONESIA)
}

\author{
Santri E. P. Djahimo \\ sunthree_dj@yahoo.com \\ English Department, Nusa Cendana University, Kupang
}

\begin{abstract}
This writing is about management of innovation in language teaching and it is reflected by a case study of managing innovation in rural schools in East Nusa Tenggara (NTT) Province, Indonesia. The content of this writing mostly discusses about how to manage innovation in language teaching. However, there are several minor parts describe about the case study conducted in rural schools in NTT Province. Innovation in education is not a totally new thing to be discussed. Many researchers as well as writers have given great attention to this topic for many years. Innovation in this study means a new way of doing something to make an improvement to someone or something. In this case, an innovation in the form of teaching methodology has been implemented to create a better atmosphere in the classroom and an improvement in the students' performance in vocabulary acquisition in EFL classroom. It has been expected that through this innovation, the students' performance would be better in vocabulary acquisition and so a better output could be achieved. Through this writing, the writer would like to show that educational innovation needs to be applied, especially by those who want better changes in order to improve themselves and achieve better results in education. The success and failure of this kind of innovation will be determined by several essential factors included in the three big category, namely Knowledge and Skill factors; Resource and Support factors; and Human and Social factors, as well
\end{abstract}


as characteristics and attributes. These factors determine whether or not an innovation in education can be adopted.

Key words: Management, Innovation, Managing Innovation, Language Teaching, Rural Schools

Abstrak: Tulisan ini memuat tentang inovasi pada pengajaran bahasa yang direfleksikan oleh suatu studi kasus tentang bagaimana menerapkan inovasi pada sekolah-sekolah di daerah terpencil di Propinsi Nusa Tenggara Timur (NTT), Indonesia. Sebagian besar dari isi tulisan ini memuat tentang bagaimana menerapkan inovasi, khususnya di dalam pengajaran bahasa. Akan tetapi ada bagian-bagian kecil yang membahas tentang studi kasus yang dilaksanakan di sekolah-sekolah pada daerah terpencil di Propinsi NTT. Inovasi pendidikan bukanlah hal baru untuk didiskusikan. Banyak peneliti dan penulis yang yang telah membahas tentang masalah ini selama bertahun-tahun. Inovasi yang dimaksud di dalam studi ini adalah suatu cara yang baru untuk membuat atau menciptakan sesuatu atau seseorang menjadi lebih baik. Di dalam hal ini, suatu inovasi dalam bentuk metode pengajaran telah dicoba untuk diimplementasikan untuk menciptakan suasana belajarmengajar yang lebih baik di kelas, dan juga untuk menghasilkan peningkatan pada performa siswa dalam hal pembelajaran vocabulary pada kelas Bahasa Inggris. Diharapkan bahwa melalui penerapan inovasi ini, perfoma siswa menjadi lebih baik sehingga menghasilkan output yang lebih berkualitas. Melalui tulisan ini penulis ingin menunjukkan bahwa perlu adanya penerapan dalam inovasi pendidikan, khususnya oleh pihak-pihak yang menginginkan adanya perubahan ke arah yang lebih baik dalam dunia pendidikan. Sukses atau gagalnya jenis inovasi ini ditentukan oleh beberapa faktor penting yang termasuk di dalam tiga kategori besar, yaitu faktor pengetahuan dan ketrampilan, faktor sumber-sumber pendukung, dan faktor manusia dan sosial, dan juga karakteristik dan atribut. Faktor-faktor ini yang dapat menentukan apakah suatu inovasi pendidikan dapat dipakai atau tidak.

Kata kunci: Manajemen, Inovasi, Manajemen Inovasi, Pengajaran Bahasa, Sekolah-Sekolah di Daerah Terpencil

\section{INTRODUCTION}

Miles (1964) dealing with educational innovation, writes that although the change in education is slow it exists. Nicholls (1983) sees innovation as 
something that will cause waste of money, time and effort if it cannot be managed in a very effective and serious way.

De Lano et al. (1994) review the reasons why educational change occurs and give three reasons for that; first, it may occur because there is a problem, and the result of the problem identification is the occurrence of educational change; second, it can occur based on the research recommendation, such as, there is a need to improve in teaching learning performance, for example in teaching methodology, teaching materials, et cetera. After conducting the research and looking at the research finding, then an educational change is proposed to be applied. In this case, research and innovation relate to each other. The relationship between research and innovation mentioned earlier can be seen in Wagner's opinion below, in which he asserts that,

Research on foreign language teaching and learning has been closely connected with the history of innovation in language teaching. New developments in linguistic theory and language learning theory have repeatedly fostered new methods in foreign language teaching (Wagner, 1988, p. 99).

In which he tries to say that research and innovation in language teaching and learning connect each other, and that research has proved that by having innovations in linguistics and language learning theory, many new methods have been found in language teaching. The third reason is it may occur because of the promotion by the change agents. And there are still many voices of other writers about innovation and how it should be managed (Henrichsen, 1989; White, 1988; Kennedy, 1988; Beretta, 1990; Fullan, 1982; Rudduck, 1991).

Innovation can also be seen as a pathway to improving teachers' teaching qualification through in-service training, as stated by Waters:

The literature on innovation theory in general and educational change in particular, both outside and within ELT, was seen as also providing a number of 'messages' which supported and supplemented the picture presented by the INSET (in-service training) literatures (Waters, 2006, p. 34). 


\section{WHAT IS INNOVATION?}

Innovation is defined in many ways. One definition comes from White (1988) who says that innovation is a process that is considered new which is consciously done with the expectation that it will make a better change to the present or future condition than the previous one. He tries to emphasize here that innovation is not the same as change which is only seen as a difference over time. A similar definition is given by Nicholls, and the way she defines it is as follows;

An innovation is an idea, object or practice perceived as new by an individual or individuals, which is intended to bring about improvement in relation to desired objectives, which is fundamental in nature and which is planned and deliberate (Nicholls, 1983, p. 4).

Another definition comes from Havelock (1973) who defines innovation as any kind of change which is considered new and has never been applied before for those who adopt it by change agents (those who bring the change). Miles (1964) has a quite similar definition that innovation is a kind of change, but he adds crucial information by stating that innovation is not an accidental change that happens all of a sudden but it takes much deliberation and need to be well planned.

De Lano, Riley, and Crookes (1994) give another definition of innovation in a more specific context of EFL relates to change, development, novelty, and improvement by saying that,
An innovation in a second language teaching programme is an informed change in an underlying philosophy of language teaching/learning, brought about by direct experience, research findings, or other means, resulting in an adaptation of pedagogic practices such that instruction is better able to promote language learning as it has come to be understood (De Lano et al., 1994, p. 489).

They then state that the definition of innovation in ESL or EFL contexts has been done by focusing on some aspects, they are; students (the development of curriculum), teachers (professional development), and those who concern with administration (the development of program). In this present study, the focusing aspects are only on students and teachers. 
From those definitions above, we know that innovation is a conscious process in achieving a better change or improvement to the previous condition through the implementation of sources which can later be adopted. There are two reasons mentioned by De Lano et al. (1994) that can be applied in this study. The first one is used for the preliminary trial of this innovation. These schools have some problems in vocabulary teaching and learning, and so this innovation is needed. The second reasons can be applied for the schools to adapt this innovation, based on the results of research done.

In a more complex way, innovation can be referred to as "incremental, radical, and revolutionary changes in thinking, products, processes, or organizations" (wikipedia). This also applies to the specific condition of teaching and learning English, as stated below;

The assumption is that a much greater development would be found ... in the adoption of [an] almost revolutionized system of teaching of English (Memorandum, "12 ${ }^{\text {th }}$ meeting on English Teaching Method”, 1956 in Henrichsen, 1989, p. 1).

My understanding is that the necessary improvement in the [English] teaching system would require almost revolutionary change (Takagi, 1956 in Henrichsen, 1989, p. 1).

The statements above imply that innovation is closely related to revolution, but "relate" does not mean exactly the same. They both aim to make a change to the previous condition, but in a different sense. Revolution mainly relates to a paradigm shift. Miles $(1964$, p. 14) suggests a definition for revolution as "a radical, violent change in the fundamental power of a social system". A single innovation has smaller scope and minor change than a paradigm shift which tends to have dramatic and fundamental change. What mostly happens in educational field is innovation rather than revolution.

Innovation in this study means a new way of doing something to make an improvement to someone or something. In this case, an innovation in the form of teaching methodology has been implemented to create a better atmosphere in the classroom and an improvement in the students' performance in vocabulary acquisition in EFL classroom. It has been expected that through this innovation, the students' performance would be better in vocabulary acquisition and so a better output could be achieved.

Improvement and much greater development will expectedly be achieved through innovation which can encourage changes in the teaching and learning atmosphere. One of the aims of this study is to create a better change 
in the EFL classroom atmosphere, from the condition where teachers used to be the most dominant persons in the classroom to students being actively participate in the teaching learning process in the classroom. In short, the innovation aims to change the condition from teacher-centered to studentscentered.

\section{SUCCESS OR FAILURE OF INNOVATION}

Many writers say that based on some evidence many innovations lack success (Gross et al., 1971; Schmuck and Miles, 1971; Smith and Keith, 1971; Bealing, 1972; Tomlison, 1978; Nicholls, 1983). In fact, most innovations are not successful. This has been experienced by the researcher while conducting the present study. In this case, not all schools are willing to accept any kinds of innovation. Some are welcoming and happily accept it after observing and seeing the changes it can make, but others do not really care with whatever the result is, as they still stick strongly to cultural and traditional values.

About the failure of innovation, various reasons are given by O'Sullivan \& Dooley (2008). According to them, the reasons why there is a failure in innovations because neither goal definition nor alignment of actions to goals is good, and also there is a low level of both communication and community sense. Dalin states that "since innovations are seldom 'good' for everyone it would be easy to find 'failures' in any innovation" (1973, p. 232). Why innovations fail is seen as a fear of something which is unknown, as stated by Fung, (1992, p. 2), "fear of the unknown is one major reason why change is not a welcoming activity". A study on the difficulties of introducing innovation successfully, especially in English language education in the East Asian region, has also been conducted by Waters and Vilches (2008, p. 6). The difficulties they describe include financial constraints, shortage of adequate facilities, a lack of qualified teachers, and a lack of learning resources. These difficulties would be very familiar to teachers working in rural areas of Indonesia.

What is mentioned earlier is exactly like the condition of one of the schools taken as the sample in this study which tends to reject the innovation. The school is in the region where the people are seeing innovation as a kind of threatening phenomenon for their local culture, and so makes them ignore every single change that does not belong to their culture, especially, from outsiders. 
There are some related factors that contribute to the success and failure of innovation, as innovation itself is not a simple but complex and difficult process. Hurst (1983) says that

Researchers have discovered a very large number of factors which are apparently or allegedly correlated with the process [of innovation]. There are at least 60 extant examples of one type of correlation alone, and Zaltman et al. (1977) refer to some 300 variables as being potentially involved. (Hurst, 1983 in Fung, 1992, p. 3)

From the large number of factors, Fung (1992) tries to simplify them into a kind of typology and so it will be easier to remember. Based on his typology, innovation contains a number of factors which are classified in a broad way into one of the categories below:

1. Knowledge and Skill factors;

2. Resource and Support factors;

3. Human and Social factors. (Fung, 1992, p. 3)

According to him, no matter how many and what kinds of factors are included in the process of an innovation, they will surely fall under these three broad categories. For example, in the process of innovation in teaching methodology, there are some factors included, such as:

1. the ability to create an interesting teaching materials, the creativity to link between the topic discussed and the classroom activities, et cetera, which belong to knowledge and skill factors;

2. classroom, teaching materials and other facilities, which belong to resource and support factors;

3. teachers, students, principals, school committees, parents, et cetera which belong to human and social factors;

Beside the factors mentioned above, there are also several characteristics and attributes which affect the way innovations are adopted, they are; relative advantage, compatibility, complexity, trialability, and observability (Rogers, 1983). These terms are further explained as follows. 


\section{RELATIVE ADVANTAGE}

The main aim of innovation is to create something better in teaching and learning conditions. That is why, in adapting innovations, there has to be a perception that the previous idea is not better compared to the new one. Besides, to be able to be adopted, an innovation has to bring any advantages for those who want to adopt it. The advantages can be in the aspects of economy and social status.

Compatibility: In order to be adapted, the new idea has to be compatible; not only with the present ideas but also with the needs of teachers and students as the clients and so there will not be any confusion in the implementation. An adoptable innovation has to be compatible with several factors like local values and beliefs, previously ideas, and clients' needs.

Complexity: An idea must not be too complex to be implemented, otherwise it cannot be adopted. The easier it is to be understood the faster an innovation will be adopted.

Trialability: This refers to "the degree to which an innovation may be experimented with on a limited basis". The new idea can be adopted as long as it can be tried out. By trying the new idea, there will be a bigger chance for it to be adopted.

Observability: This refers to the visibility of an innovation's result. If it is obviously seen by others then it is likely to be adopted. (Rogers, 1983, p. 15, 211)

Similarly, there are four main steps to be considered in the innovation decision process suggested by Rogers \& Shoemaker (1971, p. 25). They are;

Knowledge is acquired when someone has been introduced to a kind of innovation and tries to gain as much information as possible dealing with that kind of innovation.

Persuasion is the second step where someone starts showing his attitude towards the innovation, whether or not he is interested in it. This is a step of evaluation which includes the process of interpersonal communication and trial.

Decision is a step where someone is in the process of deciding whether to accept or to reject the innovation. 
Confirmation is the final stage. In this step, someone will try to confirm and reconfirm about the decision whether to accept or to reject the innovation. After going through this step, there is still a possibility that people will change their minds from acceptance to rejection and vice versa.

Those things mentioned earlier are important considerations in innovation decision process. In this particular study of innovation, both the typology by Fung and the characteristics by Rogers have been adopted in looking at the process of innovation in schools in rural areas and deciding whether or not that kind of innovation is adaptable. Besides, some questions raised by White need also to be considered in this study. The questions are as follows:

1. What is the innovation?

Is it an innovation in hardware, software, materials, methods, forms of assessment, et cetera?

2. What do we mean by the terms that we use? In this case, what do I mean by a new teaching methodology?

3. Why are we carrying out this innovation?

Are we carrying it out because other stake-holders have told us to; or is it in response to problems that have arisen through a drop in student motivation or achievement, or is it to relieve teachers' boredom; or what?

4. What is it for?

Is it to improve learning in particular skills; is it to raise examination performance, et cetera?

5. Who is it for?

Is it for the benefit of students or teachers? Is it for clients and sponsors? Who are the intended beneficiaries of the change?

6. Do we actually need it?

Can we really justify the innovation in terms of improvements and cost?

7. What justifications are there for it? Can we give a principled justification for the innovation? (White, 1988, p. 144) 


\section{INNOVATION-DECISION PROCESS}

The process which has to be undergone in deciding whether or not to accept an innovation is the innovation-decision process that is defined as a mental process that a person or an institution has to go through. It starts from knowing about that kind of innovation in details, having a kind of attitude towards it, making a decision whether or not to accept it, implementing that kind of innovation, and confirming this decision. One will find out as much information as possible in every step above in order to minimize the uncertainty about the affects, consequences, and results from that innovation (http://alamsetiadi08.wordpress.com/difusi-inovasi/).

However, innovation cannot stand alone in achieving success. There are other important factors which can also determine the success of an innovation, and that is how the innovator takes the variety of social, cultural and political factors for granted (Henrichsen, 1989, p. 5). A short note about culture: culture has broad meanings, defined by different people in different ways. What is meant by culture in this study is values, beliefs and behaviors of a group of people. This is supported by one of definitions of culture given by Magala which says that "culture would be a 'black box' of meanings, values, norms, and 'ways' (patterns of bahaviour, artifacts) regularly demonstrated and applied by real individuals and their groups" $(2005$, p. 6).

In the educational field, much effort has been expended to find out new ways in improving the quality of education, such as innovations in education management, media, resources, teacher training, curriculum implementation, et cetera. Teachers are the most important factor in implementing innovations at schools by adjusting them to social, cultural and political factors mentioned above. Miles supports this idea by stating that,

Educational innovations are almost never installed on their merits. Characteristics of the local system, of the innovating person or group, and of other relevant groups often outweigh the impact of what the innovation is (Miles, 1964, p. 635).

In this case, the local environment has to be considered as the one with great influence on the process of innovation. Holliday uses the term host environment for local environment in presenting the two-way process of innovation, in which there is a collaboration between innovation itself and the host environment and the innovation has to be adjusted to the local environment (see Figure 1). Meanwhile, the kind of innovation to be adopted depends entirely on what kind of change is to be made as each change has different 
elements and processes as well as analysis (Henrichsen, 1989, p. 2). In relation to this, Roger and Shoemaker present some useful types of social change in the following pattern (see Figure 2).

Figure 1. Collaboration between Innovation and Host Environment

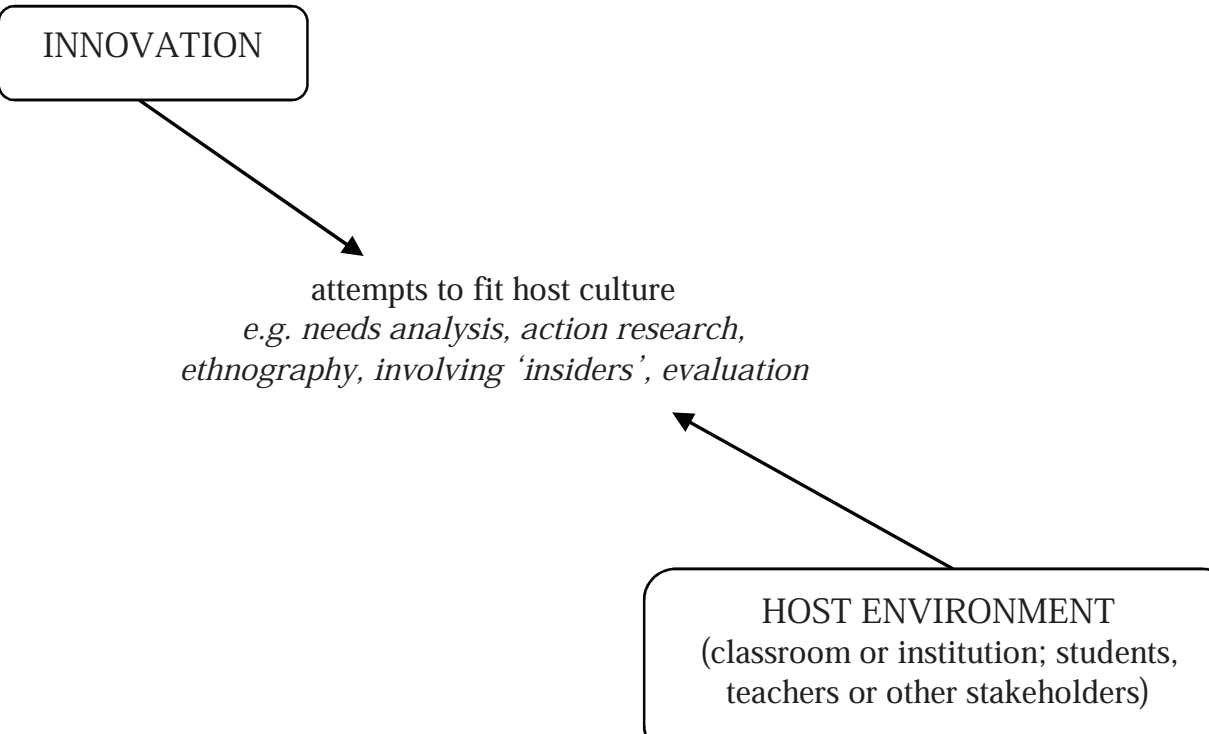

(Holliday, 2001, p. 170)

Figure 2. Paradigm of Types of Social Change

ORIGIN OF THE NEW IDEA

\section{RECOGNITION OF THE NEED FOR CHANGE}

INTERNAL:

Recognition is by members of

the social system

\section{EXTERNAL:}

Recognition may be by

change agents outside the social system
INTERNAL to the social system

I. Immanent change

III. Induced immanent change
EXTERNAL to the social system

II. Selective contact change

IV. Directed contact change

(Roger \& Shoemaker, 1971, p. 8) 
Immanent change does not deal much or even at all with outsiders but occurs within the inside members. That is why, this type of change is considered as a very simple and practical one to be done; members of the internal party know the weaknesses and also realize that changes are demanded. They then come up with a new idea to make the change.

Induced immanent change is uncommon to happen and it is not as simple as immanent change. In this type of change, the outsiders are the ones who identify the problem within the social system. However, the insiders find the solution themselves.

Selective contact change occurs when the members of a social system try to make a change within the system by selecting and adopting from other sources.

Directed contact change happens contrary to selective contact change. In this type, the outsiders use the external source to make a change through implementation of an innovation based on the purposes which have already been set by them. The typical character of this type is that it deals a lot with the outsiders as they use ideas from other sources in order to make "conscious, deliberate, and collaborative effort to improve the operations of a human system" (Roger \& Shoemaker, 1971). Every innovation has to undergo a process which involves "a series of predictable, sequential stages". This sequential stages is originally suggested by Hage and Aiken (1970:113) but is then modified by Levine $(1980$, p. 6) by adding hers. In these stages, each expert gives his/her stages in the process as can be seen in figure $3 \mathrm{c}$ below:

\section{Figure 3. Process of Innovation}

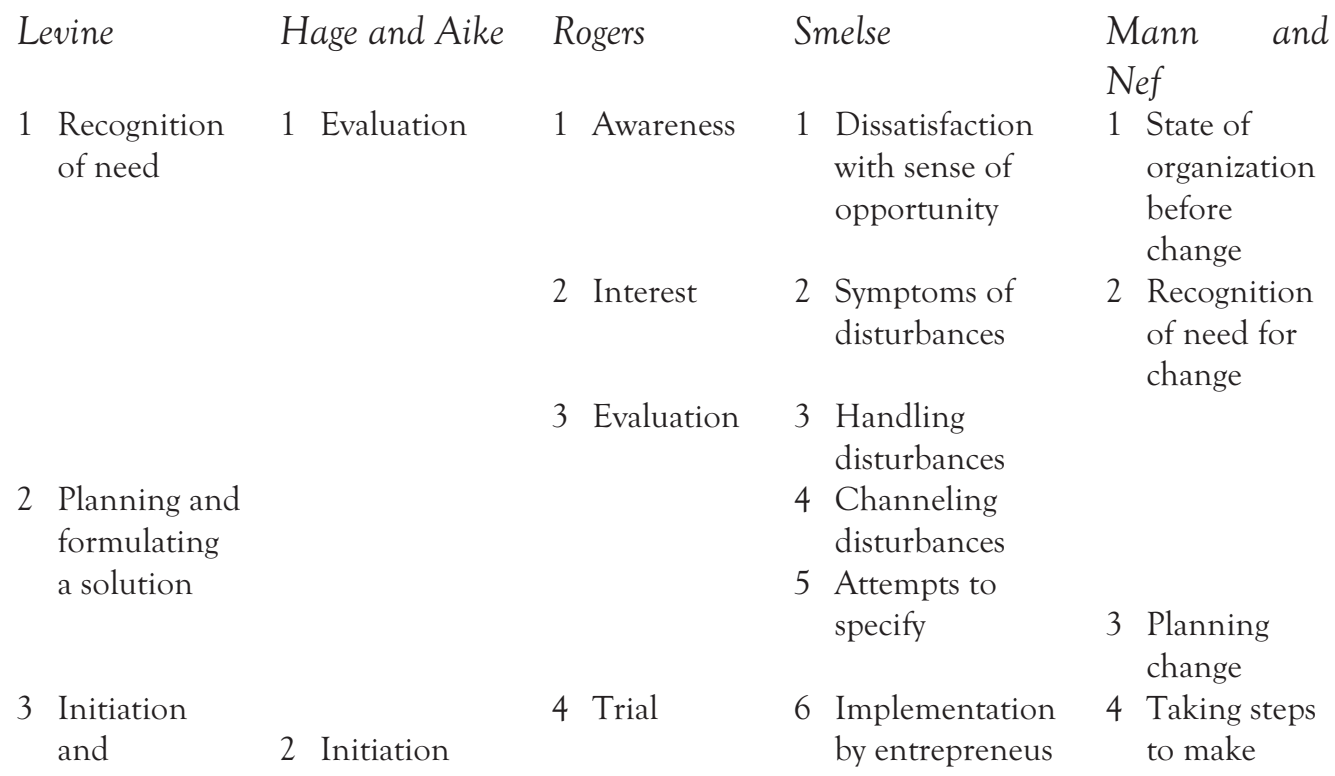




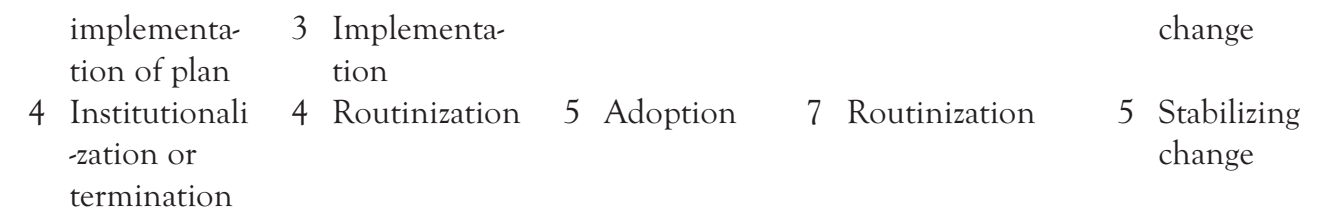

(Levine, 1980. p. 6)

Basically, all the experts have similar concepts of "stages" in the implementation of innovation although each has different terms for them. In language teaching and learning, for example, the process starts with the stage where the problem in the classroom is identified, followed by a solution which is developed to be implemented. This is the stage where the innovator attempts to introduce innovation using the appropriate implementation strategy. If it is successful, it then can be adopted to encourage new ways of teaching and learning.

In ELT innovations, another methodology has been suggested by Waters and Vilches (2001, p. 133). They divide the need for implementation into two categories, they are: levels of need and areas of need. Level of need consists of four factors. The first is familiarization, which includes those who are going to implement the innovation and the potential users, to discuss the innovation so that a familiarity is created about the innovation situation. The second level is socialization, which involves activities of modifying the innovation prototype to be based on needs analysis of the potential users and to match with their socio-cultural educational preconceptions. The third level of need is application, where the users will apply the innovation but they will be monitored and supported. The last level is integration. In this level, the users will implement the innovation without any longer being monitored and supported by the implementation team and in this phase, the innovation will become the users' "personal property" (Waters and Vilches, 2001, p. 134).

The second category of the need of implementation is areas of need. According to Waters and Vilches,

This consists of the core areas of development activity, and, therefore, of need, which ELT innovation projects potentially involve, namely curriculum development (including evaluation), teacher learning, trainer learning, and ELT management learning (Waters and Vilches, 2001, p. 135).

In the innovation tried in the present research, it can be seen that the integration phase as described by Waters and Vilches has not followed through 
or monitored, because only one site visit for field data collection could be arranged for each of the three schools. A longer-term research project would allow for such monitoring, which is clearly crucial for the sustainability of the innovation.

Havelock (1973) indicates that teachers in particular tend to resist those innovations that increase their workload. In this case, whatever innovation makes them work more and harder than they used to will tend to be rejected. They seem also to resist those innovations that threaten traditional roles (Shephard, 1967) and require the acquisition of traditional skills or knowledge. This is particularly the case in schools in rural areas which still have strong beliefs in traditional and cultural values. Schools in these areas have difficulty accepting new practices to replace the old ones even if there is recognition of the need for improvement.

Whether or not an innovation is going to be accepted also depends on how complex it is to be implemented. Lin and Zaltman (1973) have pointed out that less complex innovations tend to be more adopted than those with greater complexity as the more complex the innovations are, the more requirements to be fulfilled, such as more money, more complicated procedure, et cetera. According to them, in order to be adopted, an innovation has to be clearly advantageous. Generally speaking, people tend to accept new things which are simpler and easier. Even where an innovation is better in result, if it is complicated in implementing, it is hardly accepted.

Havelock divides the adaption process of innovation into six phases, they are : "awareness"," interest", evaluation", "trial", "adaption", and "integration". (1973, p. 113). The phases can be seen in figure 4:

Awareness: This is an initial phase, and during this phase an innovation will be introduced to an individual or a group. The first impression will be important as whether or not it will be interesting depends entirely on how it is introduced.

Interest: In the first phase, the individual or group is only as a passive interest, but in this phase, it will act as an active one, as if an individual or a group finds it is interesting about the innovation, then as much information as possible will be searched. Although the decision has not been made about whether or not the innovation will be accepted in this phase but an individual or a group has started showing attitudes towards it. If the attitudes tend to be positive then the process can be continued to the next one. 
Evaluation: In the evaluation phase, an individual or group will evaluate the innovation by trying to apply it to the local condition to be able to decide whether or not it can be implemented for trial.

Trial: In this stage, a try out of an innovation will be conducted. After going through an evaluation, the innovation will then be tried out in a small scale in his or her own condition in order to know whether or not it can be implemented for the whole situation.

Adoption: The decision of whether to accept or reject the innovation is going to be made in this phase. This will be done after seeing the results of the trial process.

Integration: This is the last phase of the process. After the decision is made, for example, to accept the innovation, then it has to be implemented in day to day use or it has to become routine and be able to integrate with the activities of teachers or whoever concerns. (Havelock, 1973, p. 13)

Figure 4. Coordinating Change Agent Activities with the Client's

\section{Adoption Activities}

\section{CHANGE AGENT ACTIVITIES CLIENT ACTIVITIES}

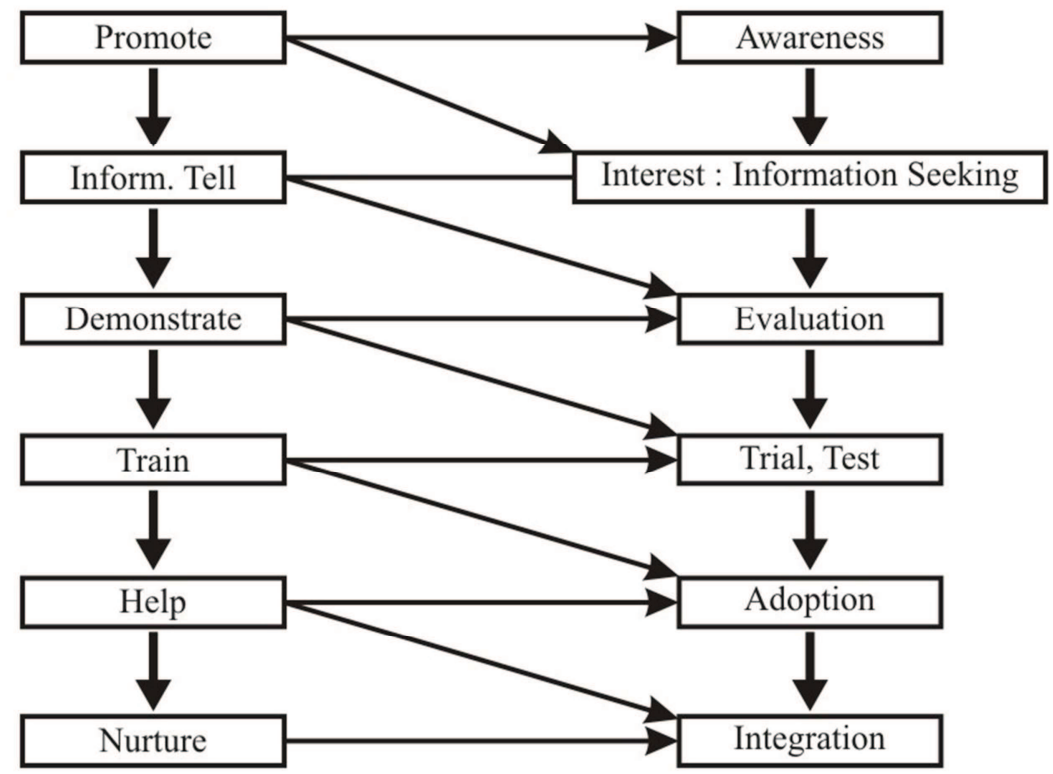


Vanterpool (1990) gives other characteristics of innovation which are more or less the same with the previous ones given by others. According to her, the characteristics of an innovation which are highly predicted to gain success can be implicitly seen from the following questions:

1. Relative advantage (compare with what exists)

a. Will it be more effective in improving learning?

b. Will it be conserve resources more efficiently?

c. Will it have a position impact on the total programme?

2. Compatibility (consistent with values, experiences, needs)

a. Will it fit well with other aspects of the programme?

b. Will it be accepted?

3. Testability (can be tried on an experimental basis)

a. Has it been tested in schools like ours?

b. Can it be pilot-tested?

c. Can we use selected parts?

4. Observability (can be seen in action)

a. Can we see a live demonstration with children?

b. Can we see a videotaped demonstration?

c. Can we see variations in its application?

5. Complexity (ease of use)
a. Will teachers need special training?
b. Will it add to teachers' paperwork?
c. Benefits that result from stability, at least to certain groups, and thus resistance to change arise.

Basically, there are many good things to be considered in adopting innovations, but not all are suitable for all conditions. In this case, the models by Rogers and Fung and the questions suggested by White have been adopted, but then take into consideration the other models mentioned earlier. The results show that not all these rural schools can accept innovation in education, and the rejection relates to the three factors of Knowledge and Skill factors; Resource and Support factors; and Human and Social factors expalined earlier. This includes the factors of social, cultural, and political. 


\section{REFERENCES}

Bealing, D. (1972). The Organization of Junior Classrooms. Educational Research, Vol. 13, (3) 231-235.

Beretta, A. (1990). Implementation of the Bangalore Project. Applied Linguistics, $11(4), 321-337$.

Brown, Kimberley. (2001). World Englishes in TESOL Programs: An Infusion Model of Curricular Innovation. In David R. Hall \& Ann Hewings (Eds.). Innovation in English Language Teaching, A Reader. Routledge, 108117.

Dalin, P. (1973). Case Studies for Educational Innovation IV; Strategies for Innovation in Education. Paris: OECD/CERI.

De Lano, L., Riley, L., \& Crookes, G. (1994). The Meaning of Innovation for ESL Teachers. System, 22, 487-496.

Fullan, M. (1982). The Meaning of Educational Change. New York: Teachers College Press.

Fung, A. C. W. (1992). Management of Educational Innovations: The "Six-A" Process Model. Hong Kong: University Press.

Gross, N., et al. (1971). Implementing Organizational Innovations: A sociological analysis of planned educational change. New York: Basic Books.

Hage, J., \& Aiken, M. (1970). Social Change in Complex Organizations. New York: Random House.

Havelock, R. G., \& Huberman, M. (1978). Solving Educational Problems: The theory and reality of innovation in developing countries. Paris: Unesco.

Havelock, R. G. (1973). The Change Agent's Guide to Innovation in Education. Englewood Cliffs, NJ: Educational Technology Publications.

Henrichsen, L. E. (1989). Diffusion of Innovations in English Language Teaching; The ELEC Effort in Japan, 1956-1968. Greenwood Press.

Holliday, A. (2001). Achieving Cultural Continuity in Curriculum Innovation. in David R. Hall \& Ann Hewings (Eds.). Innovation in English Language Teaching, A Reader. Routledge, 169-177. 
Hurst, P. (1983). Implementing Educational Change - A Critical Review of Literature. Occasional Paper No. 5, Department of Education in Developing Countries, University of London Institute of Education.

Kennedy, C. (1988). Evaluation of the Management of Change in ELT Projects. Applied Linguistics, 9 (4), 329-342.

Levine, A. (1980). Why Innovation Fails. State University of New York Press.

Lin, N., \& Zaltman, G. (1973). Dimensions of Innovations. In G. Zaltman (Ed.), The Process and Phenomena of Social Change. New York: WileyInterscience.

Magala, S. (2005). Cross-Cultural Competence. New York: Routledge

Markee, N. (2001). The Diffusion of Innovation in Language Teaching. In David R. Hall \& Ann Hewings (Eds.). In Innovation in English Language Teaching, A Reader. Routledge, 118-126.

Miles, M. B. (1964). Educational Innovation, the Nature of the Problem. In Matthew B. Miles (Ed.). In Innovation in Education. Bureau of Publications Teachers College, Columbia University, 1-46.

Miles, M. B. (1964). Innovation in Education: Some Generalizations. In Matthew B. Miles (Ed.). In Innovation in Education. Bureau of Publications Teachers College, Columbia University, 631-662.

Nicholls, Audrey. (1983). Managing Educational Innovations. George Allen \& Unwin.

O’Sullivan, D., \& Dooley, L. (2008). Applying Innovation. Sage Publication.

Rogers, E. M. (1983). Diffusion of Innovations. New York: The Free Press.

Rogers, E. M., \& Shoemaker, F. F. (1971). Communication of Innovations: A Cross-Cultural Approach. New York: The Free Press.

Rudduck, J. (1991). Innovation and Change. Milton Keynes: Open University Press.

Schmuck, R., \& Miles, M. (1971). Organizational Development in Schools. In M. Miles \& R. Schmuck (Eds.), Improving Schools through Organization Development: An Overview. Palo Alto, CA: National Press Books, 1-28. 
Sergeant, S. (2001). CALL Innovation in the ELT Curriculum. in David R. Hall \& Ann Hewings (Eds.). In Innovation in English Language Teaching, A Reader. Routledge, 240-249.

Setiadi, A. (2009). Difusi Inovasi. http://alamsetiadi08.wordpress.com/difusiinovasi.

Shephard, H. A. (1967). Innovation-resisting and innovation-producing organisations, Journal of Business.

Smith, L., \& Keith, P. (1971). Anatomy of Educational Innovation: An Organizational Analysis of an Elementary School. New York: Wiley.

Tomlinson, J. (1978). Address at the Convocation of the Schools Council, reported in the daily Telegraph, 15 November.

Vanterpool, M. (1990). Innovations aren't for Everyone. Principal, 69 (4), 3843.

Wagner, J. (1988). Innovation in Foreign Language Teaching. Aila Review, 5, 99-117.

Waters, Alan. (2006). Facilitating Follow-up in ELT INSET. Language Teaching Research, 10, (1), 32-52.

Waters, A. \& Ma. Luz C. Vilches. (2001). Implementing ELT Innovations: a needs analysis framework. ELT Journal, Vol. 55, (2), April, 133-141.

Waters, A. \& Ma. Luz C. V. (2008). Factors Affecting ELT Reforms: the case of the Philippines Basic Education Curriculum. RELC Journal, 39, (1), $5-24$.

White, R. V. (1988). The ELT Curriculum: Design, Innovation and Management. Oxford: Blackwell. 